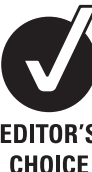

Correspondence to Alessandra Colaianni, School of Medicine, Johns Hopkins University, $9 \mathrm{~N}$ Montford Avenue, Baltimore, MA 21224, USA; ccolaia1@jhmi.edu

Received 11 November 2011 Revised 23 March 2012 Accepted 26 March 2012 Published Online First 3 May 2012

\title{
A long shadow: Nazi doctors, moral vulnerability and contemporary medical culture
}

\author{
Alessandra Colaianni
}

\section{ABSTRACT}

More than $7 \%$ of all German physicians became members of the Nazi SS during World War II, compared with less than $1 \%$ of the general population. In so doing, these doctors willingly participated in genocide, something that should have been antithetical to the values of their chosen profession. The participation of physicians in torture and murder both before and after World War II is a disturbing legacy seldom discussed in medical school, and underrecognised in contemporary medicine. Is there something inherent in being a physician that promotes a transition from healer to murderer? With this historical background in mind, the author, a medical student, defines and reflects upon moral vulnerabilities still endemic to contemporary medical culture.

On a rainy day in Oświeçim, Poland, I stood next to the rusty railroad tracks leading into Auschwitz in the same place where Nazi doctors performed 'selections', sentencing millions of innocent people to death or imprisonment by pointing left or right. Although I had spent weeks studying the role of physicians in the Holocaust as part of the Fellowships at Auschwitz for the Study of Professional Ethics, I was incredulous. The value of physicians to the Nazi regime is clear: their support gave scientific legitimacy to the principles of eugenics on which the Nazis built their Rassenpolitik (racial policy) and rationalised murder under the logic of medical necessity. Indeed, without active physician participation, the Nazi regime could not have achieved its murderous aims so efficiently: physicians disguised the horrors by systematising them and cloaking them in misleading medical jargon. In so doing, they subverted their own professional values. How could so many who had sworn to do no harm have become such an integral part of murder and torture?

What is perhaps more disturbing is the fact that the Nazi regime was neither the first nor the last to facilitate the transformation of physicians into murderers. Physician involvement in torture and murder has been a stain on the profession throughout history. ${ }^{1}$ In just the last decade, American physicians have been accused of murder in the form of 'mercy killing' during the worst of Hurricane Katrina ${ }^{2}$ and torturing prisoners in Guantánamo Bay. ${ }^{3}$ If we include murder committed in the name of scientific advancement, the number of physician perpetrators increases still further.

In discussing this issue with medical peers, I have encountered two insufficient explanations. The first is that any physicians who murdered innocent people during the Holocaust were by definition psychopaths, and would have been monsters even if the Nazis had never attained power. I find this explanation unsatisfactory due to the sheer number of physicians who participated: by 1945, half of all German physicians had joined the Nazi party, $6 \%$ before Adolf Hitler gained power (by contrast, estimates of physician membership in the American Medical Association are far lower, approximately $20 \%$ ). Furthermore, $7 \%$ of all physicians were members of the Schutzstaffel (SS), compared with less than $1 \%$ of the general population. ${ }^{4}$ While truly pathological examples exist (Drs Josef Mengele, Sigmund Rascher and Hermann Pfannmüller, among others), most doctors who participated in the Holocaust were regular people who believed that they were doing an unpleasant but morally correct and necessary job. ${ }^{4}$ In her famous analysis of Adolf Eichmann, who had been in charge of deporting Jews to death camps, Hannah Arendt coined the phrase 'the banality of evil' to describe the bureaucratic mentality with which Eichmann completed his deadly work. Eichmann, she argued, was not a monster but a conventional bureaucrat, motivated by career ambition rather than hatred for his victims. ${ }^{5}$ I view the physicians completing stacks of forms during the T4 'euthanasia' programme, recommending life or death with simple strokes of ink, in a similar light.

The second explanation I have encountered is that even if the Nazi physicians were not monsters, they were forced to participate at risk of their own deaths; they did not have free will and therefore cannot be held accountable for the 'choices' they made. However, many studies have concluded that, 'after almost 50 years of postwar proceedings, proof has not been provided in a single case that someone who refused to participate in killing operations was shot, incarcerated, or penalised in any way' ${ }^{6}$ Furthermore, a few doctors did refuse to participate-and far from being killed for their actions, they were tolerated and even, in some cases, respected for their decisions. ${ }^{7}$ Physicians joined the Nazi party and the killing operations not at gunpoint, not by force, but of their own volition.

These physicians were normal, sane individuals who chose to commit murder-but why? In social psychology, situationism describes the idea that humans make choices based on the circumstances of their social environment rather than an understanding of right and wrong. The famous obedience experiments performed by Stanley Milgram in the 1960s showed that, when instructed to do so by a person they perceived to be an authority figure, normal people willingly inflict severe pain on fellow humans. 8 These experiments demonstrated that under the right combination of pressures, anyone can commit morally heinous acts. If we accept 
a situationist perspective, then physicians who participated in the Holocaust did so, at least partly, because of the social circumstances in which they found themselves: a long history of European anti-Semitism, a new marriage of science and policy, and a Führer exhorting them to protect their race.

Situationism is not an abdication of personal responsibility: we are held morally accountable for things we do, even as a result of circumstances beyond our control. Philosophers Thomas Nagel and Bernard Williams call this concept "moral luck'. ${ }^{9}$ Although traditional Kantian ethics suggest that our moral judgement of a person should be influenced by inherent goodness or badness rather than uncontrollable circumstances, Nagel and Williams argue that in practice, we judge people who do immoral things as immoral, regardless of what role circumstances play. Nagel uses the thought experiment of two men who become equally intoxicated and drive home: a child runs out in front of the first man's car, and he strikes and kills the child. The second man is lucky: no child runs in front of his car, and he makes it home safely. Although the child running in front of the car was a product of circumstance (luck), we judge the first man as having committed a far worse crime than the second. (My use of this example is not to draw a direct parallel between the drunken driver and the Nazi physicians, but to illustrate concisely the concept of moral luck).

It is natural for us as physicians (and, in my case, as a future physician) to try to find some fundamental difference between ourselves and the Nazi doctors-to distance ourselves from the perpetrators of such heinous crimes. However, moral luck and situationism force us to consider that Nazi doctors were ordinary people operating under extraordinary conditions-and that we may have the same capacity for wrongdoing. We cannot say with certainty that, under the same circumstances, we would not have committed the same crimes. We cannot even assert that we will not do something similar in kind if our circumstances should change. Given that other physicians throughout history have made similar transformations under other circumstances, it bears asking whether there is something inherent in being a physician, or in medical culture, that promotes this transition. As one Holocaust scholar and physician has written, 'medicine as a profession contains the rudiments of evil, and even some of the most humane acts of medicine are only small steps away from real evil'. ${ }^{10}$ This leads to an unsettling question: are there social pressures now that predispose physicians to unethical behaviour?

Through research and reflection, I have come to believe that specific moral vulnerabilities exist within the medical profession, which, when combined with enabling political circumstances, have in multiple instances facilitated the almost unfathomable transition from physician to murderer. All of the vulnerabilities I discuss are in some ways necessary parts of medical culture or of being a physician, but they occupy a vanishingly small space between being adaptive and dangerous. In the remainder of this paper I will define these vulnerabilities in contemporary medical culture, assess how they enabled physician participation in the Holocaust, and reflect on what I can do to avoid moral erosion in my own evolution from medical student to physician.

\section{MORAL VULNERABILITIES Hierarchy and socialisation}

Medical culture is, in many ways, a rigid hierarchy. Medical students answer to interns, interns to residents, residents to chief residents, chief residents to attendings, attendings to department chiefs and so on up the line. Those at the lower end of the hierarchy are used to doing what their superiors ask of them, often without understanding exactly why, and they are not always encouraged to speak up if they have concerns. Questioning superiors is often uncomfortable, for fear both of negative consequences (retaliation, losing the superior's respect) and of being wrong. I know that I am becoming rapidly socialised to this culture, learning how to behave by watching my superiors and more experienced peers. Some of this is adaptive: there is much to learn to become a doctor, and learning the right way to perform procedures, behave with colleagues and present information is crucial. On the other hand, it is easy to see how this powerful cultural pressure could become a form of indoctrination. Sleep deprivation, heightened stress levels and fear of failure are infamous in medical training-and they are also powerful tools of socialisation.

The Nazis utilised that hierarchy and power of socialisation to enlist physicians in their cause. By calling on young doctors to do their national duty as 'soldiers', they added a level to the existing hierarchy and made physicians accountable to the state. As one physician put it, "according to a "Führer order", service in a concentration camp was considered front-line duty'. ${ }^{11}$ These doctors were accustomed to reporting to superiors, so the change fit well within their existing professional paradigm. The Nazis also relied on physicians, particularly those working within Auschwitz, to adjust to their new reality by means of extreme socialisation. As one physician explained, 'Auschwitz was an existing fact. One couldn't... really be against it, you see, one had to go along with it whether it was good or bad'. ${ }^{12}$ By watching their more experienced peers perform ramp 'selections' and by commiserating with them afterwards, doctors new to Auschwitz rapidly came to view the culture of the camp as an unchangeable fact.

\section{Career ambition}

Becoming a doctor requires no small amount of ambition. Premedical classes are often large and graded on a curve; so-called 'weed-out' courses designed to discourage all but the most hardworking and dedicated from continuing on. The stereotypical pre-medical student-ruthlessly competitive, willing to do anything to get ahead, in extreme cases even cheating or sabotaging others-is so well known that it has a name: a 'gunner'. Again, some of this ambition is adaptive behaviour: the path to becoming a doctor is long and arduous, and medical schools want to make sure that the students they admit will be able to handle the workload and stress. However, there is a fine line between being motivated to succeed and being willing to compromise one's integrity to attain success.

Career ambition in medicine was commandeered by the Nazi regime. As eugenics came into prominence in the USA and UK through the work of Charles Davenport and Francis Galton, and as the Nazi party began to adopt those 'scientific' principles, savvy physicians and scientists jumped aboard in droves. ${ }^{13}$ The T4 'euthanasia' programme, which preceded the extermination camps, specifically recruited young physicians for their ambitiousness: 'T4... recruited younger men who still needed to establish themselves. Such men had to be ambitious for advancement in the new Germany'. ${ }^{14}$ Other Nazi physicians conducted human subjects research within concentration camps and published those data to advance their own careers.

\section{The 'licence to sin'}

Physicians - and even medical students - are allowed to perform actions that, in other contexts, are taboo. This begins early in medical school: in the pursuit of scientific knowledge, I and two 
classmates dissected the cadaver of a 98-year-old woman, cutting her muscles apart with scalpels and cleaving her bones with a saw. Forcing an intubation tube down an unconscious person's throat, removing a dead person's heart and placing it in a live person's chest, drilling holes in someone's skull-these actions are allowed when they are performed by physicians, but are the stuff of horror films and criminal cases when nonlicensed personnel attempt them. Physicians make high-stakes, life-and-death decisions that outsiders are not allowed to make; for example, in evaluating which patients to recommend most strongly for a transplant operation when limited donor organs are available. These extra rights and responsibilities are carefully meted out through rigorous training and licensing procedures, but they may also lead physicians to arrogance or a belief that they are above the law. ${ }^{15}$ This 'licence to sin' is not confined to the hospital: as of 2007, 38 states allowed the death penalty and of those, 17 required and 18 permitted the presence of a physician during executions. ${ }^{16}$

This 'licence to sin' was crucial to medicine within the Nazi regime. By having a doctor make every decision that sent an innocent person to death, murder became a medical procedure. Actions that were unacceptable for a state to undertake became acceptable if a physician did them. In the T4 'euthanasia' programme, three junior physicians marked brief questionnaires about mentally handicapped individuals with a red ' + ' (for death) or a blue '-' (for life). In this way murder was systematised, sanitised, 'medicalised' and sanctioned. ${ }^{17}$ To the physicians who volunteered for these tasks, whether they should be allowed to condemn someone to death seemed not to be a question: they were already permitted to do things ordinary citizens could not do, and selections were one more special responsibility.

\section{Inflicting pain}

Although causing another human to feel pain sickens me (I have been told that I am 'not hitting patients hard enough' to elicit reflexes), I know that I must eventually get used to the idea. Doctors must become comfortable inflicting transient pain and discomfort on their patients for their own benefit-in the form, for example, of stitches and biopsies. It is unpleasant to hurt another human, but sometimes it is a physician's duty to cause pain in order to heal-a physician who is too tentative may cause further pain either by prolonging or having to repeat the procedure. The fact is, physicians inflict pain every day-but whatever pain they inflict is ideally both agreed to by the patient and in the patient's best interests. That said, there are doctors who do not worry enough about whether they are hurting their patients: overutilisation of CT scans, for example, is widespread and can lead to an unnecessarily increased risk of cancer. ${ }^{18}$

In Nazi Germany, being comfortable inflicting pain to achieve a future benefit was crucial to the transition from physician to murderer. In this case, though, the physician's duty was explicitly shifted from the health of his individual patients to the health of the German Volk (populace). As Dr Rudolf Ramm, author of an influential eugenics manual, opined, each doctor should be a 'physician to the Volk', a 'biological soldier'. ${ }^{19}$ Continuing the soldier analogy, one former Nazi physician noted, 'It was a matter of loyalty and sacrifice, for, as he came to feel, "the soldiers at the front also had to do things they did not like". The claim of his responsibility lay not with the patients but with his superior, his country, his race'. ${ }^{20}$ After this shift in responsibility, Nazi physicians justified the infliction of pain and death on millions of people using the same logic we use when putting patients through painful procedures. The words of Dr Fritz Klein, a Nazi physician, perfectly illustrate this logic: 'Of course I am a doctor and I want to preserve life. And out of respect for human life, I would remove a gangrenous appendix from a diseased body. The Jew is the gangrenous appendix in the body of mankind. ${ }^{21}$

\section{Medical terminology and euphemism}

Medicine, and the scientific research on which much of medicine is based, explicitly removes linguistic evidence of human action from its proceedings. Scientists use euphemisms and the passive voice in journal articles-writing 'the animals were sacrificed' at the end of the experiment is less jarring than admitting that 'I killed 20 mice by holding their necks and pulling their tails until their spines snapped.' In medicine, we routinely use the words 'idiopathic' or 'cryptogenic' to mean, 'we don't know', and 'iatrogenic' or 'nosocomial' to mean, 'we caused it'. Patients who disagree with our assessments are deemed 'difficult', 'noncompliant', or can leave 'AMA' (against medical advice). It is necessary for medical language to be specific-calling something an erythematous zosteriform lesion will mean the same thing at every hospital, and that is a good thing for the practice of medicine. However, overuse of medical jargon can be dangerous when it leads to dehumanisation, equivocation, or euphemism.

Physicians in Nazi Germany used euphemism to great effect. They were not murdering mentally handicapped individuals with poisonous gas; they were 'euthanising' Lebens unswertesleben (literally, 'life unworthy of life'), 'cleansing' or 'disinfecting' German genetic stock. ${ }^{22}$ They were not sending children and families to die by suffocation; they were 'selecting' them for 'special treatment' (Sonderbehandlung) or Terapia Magna Auschwitzciense in 'showers'. They were not murdering individual humans, they were ridding their country of, as Klein stated, a 'gangrenous appendix'. By using this language, Nazi physicians were able to rationalise and intellectualise what they were doing, living with their crimes while detaching from them further. ${ }^{23}$

\section{Detachment}

Physicians are more at ease in the presence of pain, sickness, morbidity and death than are their citizen counterparts; the medical profession requires unflappability in the face of things that others would consider disgusting, horrific, or otherwise overwhelming. On an intellectual level, I know I will not be able to treat a patient with a serious injury optimally if I am too sickened by the sight of the wound to stitch it up; my peers and I have been warned against getting so emotionally invested in our patients that we lose the ability to 'leave work at work'. This is often referred to as clinical detachment, or 'detached concern'-showing empathy and caring, but not so much that you burn out emotionally. I have trouble with this concept, and with the way that it is treated as an unspoken requirement of being a doctor. Some detachment may be necessary to practise medicine, but it is a very fine line, and there is no objective way to tell how much is too much. This is something that I struggle with even now, this idea of professionalism that is sometimes taken to mean that physicians are not allowed to have controversial opinions, a personality, or anything but a fresh face and a white coat. In my more skeptical days, it has occurred to me that I am being asked to create a 'doctor self' that is entirely separate from my personality.

Physicians in Auschwitz had to use their considerable powers of detachment simply to exist in a place so horrific that one of them called it anus mundi, the anus of the world. Just as I am creating my 'physician personality', Nazi doctors used 'doubling' or 'splitting' to distinguish their outside selves from their 
'Auschwitz selves'. Because those physicians were accustomed to being stoic, because not reacting was something they knew was expected of them, they quickly adapted to the grim realities of their lives at Auschwitz. Therefore, standing at the edge of the ramp, pointing hundreds of people at a time to their painful deaths became just another disagreeable but necessary task: 'For most SS doctors, selections were a job-somewhat unpleasant and often exhausting. ${ }^{24}$ No matter how disturbing new recruits found the task, '...in time most were capable of efficiently carrying out their duties'. ${ }^{25}$ Their powers of detachment were so strong that, as one physician who had worked in Auschwitz noted, 'In the beginning it was almost impossible. Afterwards it became almost routine. That's the only way to put it' ${ }^{26}$

\section{CONCLUSIONS: WHAT CAN BE DONE?}

As I continue my medical education, the question that keeps me awake at night is how I can lead an ethical life regardless of my circumstances-how I can navigate these moral vulnerabilities and remain morally intact. It is well documented that medical students become less empathetic ${ }^{27}$ and even less ethical ${ }^{28}$ as we progress through medical school; perhaps one part of leading an ethical life as a physician, then, is not allowing one's existing moral compass to be recalibrated by authority or socialisation. Within the Milgram experiments there were individuals who refused to inflict pain on their subjects; within Nazi Germany, some doctors spoke out. It is for this reason that a solid grounding in principles of ethics, individualism and human rights is so crucial for physicians and others in positions of power or trust. Being aware of the risks and potential for harm inherent in our chosen profession is important, and actively modifying deleterious aspects of medical culture is as well. On my first day of anatomy dissection, we held a 'humanisation' ceremony to thank the donors, remembering explicitly that they were people to be treated with the utmost respect. Pass-fail classes, increasingly popular in medical schools, are designed to combat the more pernicious effects of a competitive atmosphere. Residency work-hour restrictions in the USA are intended to reduce trainee exhaustion and burnout. Medical culture is evolving, and as it evolves, we should endeavour to make it more difficult for physicians to succumb to the dangerous sides of these moral vulnerabilities. The Nazi physicians cast a shadow on our profession. We must escape that shadow by guarding against our own moral erosion.

Funding This work was supported by the Fellowships at Auschwitz for the Study of Professional Ethics programme.

Competing interests None.

Provenance and peer review Not commissioned; externally peer reviewed.

\section{REFERENCES}

1. Clare A. Medicine Betrayed: The Participation of Doctors in Human Rights Abuses London, UK: Zed Books Ltd in association with the British Medical Association, 1992.

2. Sheri F. The deadly choices at memorial. The New York Times Magazine 30 August 2009:MM28.

3. Allen S, Keller A, Reisner S, et al. Aiding torture: health professionals' ethics and human rights violations revealed in the May $2004 \mathrm{CIA}$ inspector general's report. Physicians for Human Rights. 2009. http://physiciansforhumanrights.org/library/ reports/aiding-torture-2009.html (accessed Oct 2011).

4. Caplan AL. How did medicine go so wrong? In: Caplan A, ed. When Medicine Went Mad: Bioethics and the Holocaust. Totowa, NJ: Humana Press, 1992:53-92.

5. Arendt H. Eichmann in Jerusalem: A Report on the Banality of Evil. New York, NY: Penguin Classics, 2006.

6. Friedlander H. The Origins of Nazi Genocide: From Euthanasia to the Final Solution. Chapel Hill, NC: The University of North Carolina Press, 1995:235-6.

7. Lifton RJ. The Nazi Doctors: Medical Killing and the Psychology of Genocide. New York, NY: Basic Books, 2000:303-35.

8. Blass T. Psychological perspectives on the perpetrators of the Holocaust: the role of situational pressures, personal dispositions, and their interactions. Holocaust Genocide Stud 1993; 7:30-50.

9. Nagel T. Mortal Questions. Cambridge, UK: Cambridge University Press, 1979:24-38.

10. Grodin MA. Mad, bad, or evil: how physician healers turn to torture and murder. In: Rubenfeld S, ed. Medicine After the Holocaust: From the Master Race to the Human Genome and Beyond. New York, NY: Palgrave MacMillan, 2010:58.

11. Lifton RJ. The Nazi Doctors: Medical Killing and the Psychology of Genocide. New York, NY: Basic Books, 2000:198.

12. Lifton RJ. The Nazi Doctors: Medical Killing and the Psychology of Genocide. New York, NY: Basic Books, 2000:196.

13. Grodin M, Annas G. Physicians and torture: lessons from the Nazi doctors. Int Rev Red Cross 2007:867:635-54.

14. Friedlander H. The Origins of Nazi Genocide: From Euthanasia to the Final Solution Chapel Hill, NC: The University of North Carolina Press, 1995:221.

15. Berger AS. Arrogance among physicians. Acad Med 2002;77:145-7.

16. Black L, Sade RM. Lethal injection and physicians: state law vs medical ethics. JAMA 2007:298:2779-81.

17. Friedlander H. The Origins of Nazi Genocide: From Euthanasia to the Final Solution Chapel Hill, NC: The University of North Carolina Press, 1995:219.

18. Brenner DJ, Hall EJ. Computed tomography: an increasing source of radiation. $N$ Engl J Med 2007;257:2277-84.

19. Perper JA, Cina SJ. When Doctors Kill: Who, Why, and How. New York, NY Copernicus Books, 2010:63.

20. Lifton RJ. The Nazi Doctors: Medical Killing and the Psychology of Genocide. New York, NY: Basic Books, 2000:106

21. Lifton RJ. The Nazi Doctors: Medical Killing and the Psychology of Genocide. New York, NY: Basic Books, 2000:16.

22. Friedlander H. The Origins of Nazi Genocide: From Euthanasia to the Final Solution. Chapel Hill, NC: The University of North Carolina Press, 1995:231.

23. Grodin MA. Mad, bad, or evil: how physician healers turn to torture and murder. In: Rubenfeld S, ed. Medicine after the Holocaust: From the Master Race to the Human Genome and Beyond. New York, NY: Palgrave MacMillan, 2010:54.

24. Lifton RJ. The Nazi Doctors: Medical Killing and the Psychology of Genocide. New York, NY: Basic Books, 2000:193.

25. Perper JA, Cina SJ. When Doctors Kill: Who, Why, and How. New York, NY Copernicus Books, 2010:61.

26. Lifton RJ. The Nazi Doctors: Medical Killing and the Psychology of Genocide. New York, NY: Basic Books, 2000:195.

27. Neumann M, Edelhäuser F, Tauschel D, et al. Empathy decline and its reasons: a Systematic Review of studies with medical students and residents. Acad Med 2011;86:996-1009.

28. Self DJ, Baldwin DC. Does medical education inhibit the development of moral reasoning in medical students? A cross sectional study. Acad Med 1998;73 (10 Suppl):S91-93 